This article was published in THE CURRICULUM JOURNAL Vol.22 No. 1, March 2011 , pages 81-76

\title{
The Transition Year Programme in Ireland. Embracing and resisting a curriculum innovation
}

Gerry Jeffers

National University of Ireland, Maynooth

353-1-7086087

gerard.jeffers@nuim.ie 


\title{
The Transition Year Programme in Ireland. Embracing and resisting a curriculum innovation.
}

\begin{abstract}
The Transition Year (TY) Programme is an optional, one-year, stand-alone, full-time programme offered in 75\% of second-level schools in the Republic of Ireland. Aimed at those in the 15-16 age group, TY has a strong focus on personal and social development and on education for active citizenship. The implementation of TY in schools is seen as a case study in curriculum innovation. Evidence from the programme's history and development, from studies of attitudes to TY in six schools and among policy shapers suggests ambiguous views among stakeholders towards the programme. Enthusiasm for aspects of the innovation is accompanied by resistance to its more challenging features. Schools' responses to the programme is examined from a range of perspectives.
\end{abstract}

Keywords: Transition Year; Ireland; curriculum development; curriculum innovation

\section{Introduction}

In a world of rapid change, school systems grapple continually with issues of curriculum innovation and implementation. The robust nature of established practices is often identified as a contributory factor in sub-optimal realization of admirable and ambitious aspirations (e.g Sarason (1990, 1996, Eisner 1992, Tyack and Cuban, 1995, Fullan 2001, McCulloch 2005, Sugrue et al, 2008 ). While the case of the Transition Year programme in the Republic of Ireland illustrates how schools in particular contexts engage with the implementation of a specific innovation, it also offers pointers to wider issues associated with the introduction of curricular initiatives into schools.

\section{Background}

The Transition Year (TY) Programme is an optional, one-year, stand-alone, full-time programme offered in $75 \%$ of second-level schools in the Republic of Ireland. TY takes place immediately after the three-year Junior Certificate (JC) Programme and prior to a 
two-year Leaving Certificate (LC). Hence, the majority of TY students are aged 15-16 years. TY has a strong focus on personal and social development and on education for active citizenship. (Ireland, Department of Education, 1976, 1993, 1996). The invitation to schools is to devise a broad holistic educational experience that promotes maturity, greater responsibility in students for their own learning and decision-making (Ireland, Department of Education, 1993, p.3). Aims include increased social awareness and social competence with 'education through experience of adult and working life' as a basis for personal development and maturity (ibid. p.4).

In a schooling system that is highly centralized and dominated by the effects of a high stakes public examination,(the LC), TY is strikingly different from other school programmes. In addition to a particular focus on personal and social development, individual schools are given extensive freedom to design their own TY curriculum and there are no formal public examinations associated with the programme. The guidelines (Ireland, Department of Education, 1993,8) place a particular emphasis on teachers using a wide range of active teaching/learning methodologies in $\mathrm{TY}^{1}$. Thus, this ambitious innovation seeks to bring about a re-focusing on students' social competence and social awareness, a fresh emphasis on self-directed learning and intrinsic motivation, the use of more active teaching and learning methodologies by teachers, greater collegiality in schools including collaboration with parents and community interests and, overall, a more holistic view of schooling generally.

TY was first introduced in 1974 but for 20 years participation rates were very low. Policy decisions that included financial incentives and practical support for schools and teachers led to a significant increase in participation from 1994 (Jeffers, 2007). In 2009-10, 53\% of the relevant age cohort (mainly 15-16 year olds) participated in $\mathrm{TY}^{2}$.

\footnotetext{
${ }^{1}$ The relevant section states that 'The goals and objectives of the programme can best be achieved by placing particular emphasis on: negotiated learning; personal responsibility in learning; activity-based learning; integration of appropriate areas of learning; team teaching approaches; group work - discussion, debate, interview, role play; project work and research; visiting speakers and seminars; study visits and field trips; work experience, work simulation, community service. Educational activities undertaken should enable students to have a valid and worthwhile learning experience with emphasis given to developing study skills and self directed learning.' (Ireland, Department of Education, 1993, p.8)

2 e-mail communication for Statistics Section, Department of Education and Skills, 26 ${ }^{\text {th }}$ July 2010
} 


\section{Purpose}

This paper presents and discusses data relating to six different perspectives on TY.

Firstly, patterns of uptake are presented. Second, the evidence of how schools interpret TY is examined. Next, the respective views of teachers, parents and students are considered. Finally, some attitudes of policy makers are explored. The intention is to offer pointers to improving practice within Ireland while at the same time indicating features which may have a relevance to implementing curriculum innovations elsewhere.

\section{Data sources}

This paper is based on three distinct enquiries. Firstly, the history and development of TY is based primarily on the (limited) official documentary evidence of TY's development. This is complemented by an interview, conducted in 2001, with the Minister for Education who initiated the TY programme in 1974.

Second, adopting a mixed methods approach, both quantitative and qualitative methods were used in exploring the following research question:

- What are the attitudes of the critical actors - students, teachers, parents and school leaders - towards TY and how do these attitudes manifest themselves in the operation of TY at six distinct school sites?

Data gathering consisted of five main methods: 16 individual interviews with school principals and TY co-ordinators; 26 focus group interviews involving 111 students; 2 focus group interviews with 10 parents; an extensive teacher questionnaire completed by 113 teachers, documentary evidence in the form of published and unpublished material from each of the six schools (Jeffers, 2007).

Third, data from nine hour-long, semi-structured interviews with key policy shapers provides valuable indicators of the views of such strategically positioned personnel as the Chief Inspector of the Department of Education and Science, the Chief Executive of the National Council for Curriculum and Assessment, and the Directors of various support services and teacher union representatives (Jeffers, 2008). 
In addition to those three data sources, the author's experience as a teacher of TY programmes between 1986 and 1995 and as a member of support services for the national mainstreaming of TY between 1995 and 2000, informs the article.

\section{Unevenness of uptake}

TY was the brainchild of a Minister for Education who sprang the idea on an unsuspecting public in 1974. When interviewed about it 27 years later, he acknowledged that, prior to the announcement, his departmental officials knew little about it (Jeffers, 2007, 1). The Minister articulated his vision as follows:

Because of the growing pressures on students for high grades and competitive success, educational systems are becoming, increasingly, academic tread-mills. Increasingly, too, because of these pressures the school is losing contact with life outside and the student has little or no opportunity 'to stand and stare', to discover the kind of person he (sic) is, the kind of society he will be living in and, in due course, contributing to, its shortcomings and its good points. The suggestion was made that perhaps somewhere in the middle of the course we might stop the tread-mill and release the students from the educational pressures for one year so that they could devote time to personal development and community service (Burke, 1974).

In the September following the announcement, only three out of nearly 800 possible schools offered TY. Revised guidelines and another attempt to broaden uptake more than a decade later brought participation rates towards $10 \%$ of the relevant age cohort. Significantly, much of this growth was among young people attending the relatively small number of schools that charge fees (Doyle, 1990, 20). Major changes in participation rates date from the 1994 when more than $30 \%$ of the cohort took part, an increase of $148 \%$ on the previous year. Two interrelated factors contributed strongly to the growth. Firstly, a relatively small additional grant ${ }^{3}$ was given to schools for each student participating in TY. Second, the Department of Education put in place a dedicated team of teachers seconded from schools to offer peer support for those implementing the programme. Indeed, availing of this service was a condition attached to receiving the money. In the subsequent years, the programme has expanded so that

\footnotetext{
${ }^{3}$ When first introduced in 1994, the additional annual grant to schools was IR£50 per TY student. Despite inflation and a booming economy, this remained unchanged for 13 years. When the currency changed to euros in 2001, the annual grant remained at €63.49. In September 2007, this was increased by the Department of Education and Science to $€ 100$ per student. In the budget of October 2008, this and similar grants related to other school programmes were withdrawn and a new system of supporting schools was introduced.
} 
$75 \%$ of schools offer it. Within some schools, TY is optional and, as already noted, just over $50 \%$ of the relevant cohort now follow it.

This effectively means that, of the $82 \%$ of teenagers who complete a LC, half of them have taken five years while the other half - those who opt for TY - not only benefit from six years of schooling but also get the enrichment associated with TY activities. ${ }^{4}$ Closer examination of participation patterns reveals higher levels of uptake among girls, in schools that charge fees and in schools in the (relatively better off) east of the country (Jeffers, 2002). There are corresponding lower levels of participation among boys, particularly those from family backgrounds with low levels of formal schooling, and in small and rural $\mathrm{VEC}^{5}$ schools. However, there are sufficient anomalies within these broad trends- or 'outliers' (Gladwell, 2008) - to suggest that some individual schools, including those designated as 'disadvantaged', not only choose to embrace TY but succeed in sustaining worthwhile programmes which students and their parents value. ${ }^{6}$ Notwithstanding that, the fundamental problem of imbalance in the allocation of resources related to five and six year pathways though second-level schooling remains. Thus, an issue arises when the implementation of any innovation is left to the discretion of a school: on the one hand those schools that opt in make conscious choices and can be empowered by this and seem more likely to work at its successful implementation; at the same time, while a variety of factors can impact on a school deciding not to engage with an innovation when it is optional, the evidence suggests it is less likely to do so when it is already dealing with significant disadvantage (including children from families with

\footnotetext{
${ }^{4}$ Two studies (Miller and Kelly, 1999; Smyth et al, 2004) have demonstrated a direct correlation between doing TY and higher grade achievement in the LC examination. Admission to university and other thirdlevel educational institutions in Ireland is by means of a points scale based on results in six LC subjects. With a maximum possible score of 600, an average points difference of 26 between those who take TY and those who do not is very significant. While improving LC grades was never an explicit goal of TY, this research has, in effect, been very reassuring for those who fear that TY's emphasis on social and personal development might contribute to a decline in academic standards. However, this in turn raises questions as to the extent to which schools offer a 'pure TY' or 'a three-year LC'.

${ }^{5}$ Vocational Education Committees administer about one third of the second-level schools in Ireland. The majority of second-level schools are classified as 'voluntary secondary schools'. There are also Community and Comprehensive Schools at second-level. A brief description of the Irish education system, including a schematic diagram is available at http://www.education.ie/servlet/blobservlet/dept education_system.pdf

${ }^{6}$ In a study of attitudes to TY in six schools were the programme was 'well-regarded', two of the schools were classified as 'disadvantaged'. Extensive evidence from both schools suggested that TY had very enriching effects of student development, motivation, achievement and on school climate. (Jeffers, 2007)
} 
very limited incomes, children with low levels of literacy and numeracy, children with serious behaviour problems, limited resources and sometimes overstretched staffs) even if the innovation's potential is great.

\section{Schools adaptations of TY programmes}

The curriculum tradition in Ireland has been strongly ‘top down’. The rigidity of centrally prescribed programmes has been further consolidated by a single nationwide examination system. A culture of teaching for the examination, particularly the LC, is strongly embedded in schools. As Looney has remarked, there is little empowerment associated with curriculum. She describes it as 'something for teachers, students and schools to overcome, to manage, to conquer' (Looney, 2001, 151). Many teachers approach this task in terms of a formal pedagogy with a strong dependence on textbooks, analysis of previous examination questions and rote learning. Even at primary level, where a child-centred approach has been part of official policy since 1971, Sugrue (1997, 25) noted that while teachers endorse the rhetoric of progressive teaching methods, data on actual practice suggests a more formal style. Gleeson $(2004,2010)$ has demonstrated that technical rather than practical or emancipatory interests dominate curriculum policy and practice in Ireland.

The invitation to school and teachers at the heart of the TY project is to challenge many deeply held traditions. 'Curriculum content is a matter of selection and adaptation by the individual school....' (Ireland, Department of Education, 1993, 5). Teachers are seen as facilitators of learning, employing active methodologies and formative assessment.

Responses to such a carte blanche have been mixed. An emerging pattern observed by the support services ${ }^{7}$ can be outlined as follows: At least one key enthusiast is professionally energized by the possibilities offered by TY. S/he seeks allies, including

\footnotetext{
${ }^{7}$ When mainstreaming TY in 1994, the Department of Education made it a condition of participation that schools engage with 'programmes of staff development/inservice education' (DES, 1993, p.13). These programmes were facilitated by regionally based support teams of teachers which developed into a team of 14 seconded teachers between 1995 to 1998. The TY support service was then downsized to a team of six, further reduced in 2000 and them integrated with other programme and subject support services into the Second-Level Support Service (SLSS) that operated between 2001 and 2010. The SLSS is due to be subsumed into the Professional Development Service for Teachers (PDST) in late 2010 (www.slss.ie) .
} 
the school's leadership and sets about shaping a programme. When this enthusiast becomes the co-ordinator, the tendency is to offer imaginative educational activities, often as once-off experiences. Feedback from students highlights an appreciation of opportunities for learning beyond conventional classrooms: work experience placements, community service activities, field trips and the use of visiting speakers are especially popular. Students also talk warmly about improvement in student-teacher relationships within TY, often linked with excursions out of the conventional classroom. Of course, not all teachers are as imaginatively engaged. Many whose identities are closely linked to their students' achievements in examinations admit to finding teaching a TY class especially challenging. They often mention the absence of an examination focus. A noticeable trend with such teachers is for them to link their teaching in TY with the twoyear LC course that will follow. A result can be that students and parents then perceive parts of TY as within a 'three-year LC'. The guidelines themselves are ambiguous on the relationship between the well-established LC and TY. Consequently, or perhaps inevitably given the LC's hegemony within the system, TY is continually in danger of being colonized by the values of the LC examination and the associated 'points system' (Jeffers, 2007, 2008).

Thus, alongside enthusiasm for TY and its achievements, there is a consistent pattern of reservations. The evidence shows how schools domesticate the programme to suit particular contexts, supporting Datnow's (2002) concept of ‘co-construction’ and the large body of research that indicates how practitioners adapt, re-shape and modify educational innovations (e.g. House 1974; Eisner 1992; Sarason,1996; Fullan, 2001; McLaughlin 2006). The term domestication refers to the way that schools adapt and shape TY to integrate it into their existing priorities and practices; they tend to emphasise those aspects of TY that 'fit' with their tradition and sense of identity. Domestication also implies 'taming' and the evidence points to schools tending to downplay or even omit aspects of TY that are particularly challenging. Such resistance is seen as significant. For example, the guidelines advocate 'an interdisciplinary approach would help to create that unified perspective which is lacking in the traditional compartmentalised teaching of individual subjects' (Department of Education, 1993, 6). 
There is minimal evidence in any of the research of such approaches. Assessment - 'an integral part of the teaching and learning process' $(1993,9)$ is frequently absent from

programmes. While strongly encouraged, teacher teamwork and co-ordination by 'a core team' is often abandoned in favour of individual, relatively isolated contributions and a single co-ordinator. In many cases the dilution of TY values is accompanied by the colonisation of the programme by the values of the LC examination and the associated points system.

\section{TY: Parents' Perspectives}

Parents of TY students are generally well disposed towards the programme. Strikingly, they tend to be reluctant to make generalisations about TY, often restricting their observations to what they see in their own sons and daughters. They value, in particular, the perceived effects of greater social confidence and competence brought about by TY. They tend to highlight, in particular, the variety of learning situations outside the classroom - trips, musicals, fund-raising projects, work experience and community service placements, etc. - as valuable opportunities that enable their sons and daughters to relate to each other and to their teachers in more varied ways than within conventional classrooms.

A major finding from the data is that parents frequently state that their knowledge of TY is very limited. They would welcome opportunities to hear more about it. Parents' stated desire for more knowledge about TY contrasts starkly with teachers' perceptions; a majority of teachers believe that parents are well informed about TY. The need for schools to engage parents more in discussion about TY - and schooling in general before, during and after the programme is a clear message from the research.

Therefore, at a more general level an ambitious educational innovation needs to respect existing understandings and expectations about schooling among all stakeholders. Open dialogue between those in the school charged with implementing the innovation and stakeholders is imperative, especially at the early stages. 


\section{TY: Students’ Perspectives}

One pointer to how parents can be better informed about TY is the practice in a growing number of schools of giving TY participants a centre-stage position at information sessions about the programme. This builds on the evidence that, generally, young people tend to speak enthusiastically about TY. They highlight TY activities that involve learning beyond conventional classrooms. They value classes in which their opinions are sought and listened to. Frequently, they contrast TY with their experiences in Junior Cycle, which many of them describe as pressurised and examination-driven. Students express the contrast in various ways, for example:

(Junior Cert. classes are) forty minutes of work. It's, like, 'Good morning', and then they start writing on the board and then 'This is your homework' and 'Good bye', where you don't talk to them at all; whereas this year you get to know the teachers more in person and you can talk to them and you can interact much better. You get to know each other much more.

$$
\text { Iris, Fourth year, Oak School }
$$

We get more input. In Third year and other years you have to learn this and you have to listen to teacher, and note-taking and writing and that, but this year you get a topic and you can debate it and discuss it.

$$
\text { Eamonn, Fourth year, Chestnut School }
$$

Older students, while sharing many of the positive views of TY students, sometimes reflect an awareness of a tension between the broad education for maturity (in TY) and the demands of the LC and the associated points system of admission to third-level education. Generally, students from aged 14 to 18 indicated a range of nuanced opinions about the programme - and about their schooling experience - that underlines the value of consulting young people about curricular initiatives. One sees in such consultation that multifaceted benefits of taking seriously the thinking that informs Article $12^{8}$ of the United Nations Convention of the Rights of the Child (UN, 1989). The evidence from these studies suggest that schools need to structure greater consultation with young people about curricular initiatives designed for their benefit before and during the implementation stage.

\footnotetext{
${ }^{8}$ Article 12 obliges signatory states to 'assure to the child who is capable of forming his or her own views the right to express those views freely in all matters affecting the child, the views of the child being given due weight in accordance with the age and maturity of the child'. (see http://untreaty.un.org/English/TreatyEvent2001/pdf/03e.pdf)
} 


\section{TY: Teachers’ Perspectives}

Teachers were the most nuanced in their comments, frequently tempering their enthusiasm for the idea of TY with what they see as major challenges in implementing it. Teachers who express reservations about facets of the programme were keen to acknowledge that TY's arrival heralded some transformation in the school's climate, with increased student maturity, sense of responsibility and confidence as persistent themes. In Sycamore School, to give one particular example, the Principal observed that those who participated in TY tend to set academic standards for the whole school and demonstrate positive leadership among the student body. To support this point, he cited the strong representation of former TY students among the Sixth year prefect group (Jeffers, 2007, 230).

The altered relationships between teachers and students brought about during TY is a major consequence of the programme. This plays an important role in reducing the inherited authoritarian tradition in schools. Furthermore, the changes teachers identify in school climate as a result of TY carry engaging resonances with the vision for senior cycle education set out by the National Council for Curriculum and Assessment where 'a different school culture for senior cycle students’ (NCCA, 2003b, 4) would operate.

\section{TY: Policymakers’ Perspectives}

A range of people involved in the making and shaping of educational policy were interviewed in 2007 (Jeffers, 2008). These informants generally articulate a palpable enthusiasm for TY, for its freshness and creativity, for its developmental and liberating impacts. However, while recognising TY's undoubted enriching of existing provision in schools, two trends in particular are worth noting. Firstly, TY is often seen as inhabiting a sort of 'parallel universe', as if it is a kind of 'breathing space' or 'halting site' away from the frenetic race for points, disconnected with the more serious pursuits of the JC and LC. One consequence of this fractured thinking is that TY is increasingly seen as the site for schools to advance the personal and social development of adolescents while the other years, especially third, fifth and sixth, are increasingly seen as being about preparation for 
public examinations. Arguably, a curriculum consequence is that the existence of TY actually reduces the pressure on the system to reform programmes such as the JC and LC. For example, the need for work experience and community service activities, or more cooperative learning or more emphasis on the implications of Multiple Intelligence theory (Gardner, 1984, 1993, 1999) can seem less urgent in the JC and LC if they are promoted in TY. Such a flawed view, of course, both fails to see the secondary cycle as an integrated, coherent one and neglects the reality that a sizeable percentage of the cohort do not experience TY at all.

However, occasional glimpses that TY values have implications for the whole system are captured. For example, Eamon Stack, then Chief Inspector in the Department of Education and Science, describes one contrast as 'the traditional Leaving Cert. is focused on the subjects but TY is more student-centred' (Jeffers, 2008,.294). He notes how this manifests itself in very different teaching styles, with consequent policy implications:

Some teaching can be - let's say in a Leaving Cert. and Junior Cert. - passive enough from the point of view of the student. There are huge lessons to be learned in terms of teaching overall from Transition Year. Of course, they impact on not just continuous professional development but initial teacher training as well. (Jeffers, 2008, 318)

The second, related, trend is a sense that TY as an innovation has been 'embedded' in the system and thus has slipped down the agenda of priorities. A number of former school principals, now working in policy related positions, recalled the great apprehension associated with TY's introduction into their schools. When linked with the earlier point of domestication, it appears that what has been 'embedded' is a limited, diluted form of TY that can be accommodated by the system without too much change to the status quo; an innovation without too much change!

\section{Wider societal concerns}

Within a wider societal context, TY can be seen as an example of an attempt to reposition the place of young people and their voices. There is extensive evidence from literature and memoirs that document how Irish children 's views were ignored in schools and in 
the wider society (e.g.Arensberg and Kimball, 1948, p.38; O’Brien 1962; McGahern 1963, 2005; O’Brien, 1986; Browne,1986; McCabe,1995; Deane, 1996; Kerrigan, 1998; Hyland, 2006; McGrath 2007). More recently, various reports (e.g. Government of Ireland, 2000; Commission to Inquire into Child Abuse, 2003, 2009; Government of Ireland, 2005; Devlin 2007) are further painful reminders of what can happen in a society that does not listen to children's voices.

A major shift in thinking about young people and schooling is required. Rudduck and Flutter (2004, 139), contend that school structures, policies and practices have been crafted to ensure no student voice is possible. They believe that a central concern in the transformation of schools into learning communities, must be in altering the way students and teachers engage with learning, recalling Friere’s (1970) idea of 'culture circles' in which the voices and experience of learners are heard and valued. This perspective builds on Stenhouse's $(1975,208)$ belief that only teachers can really change the world of the classroom, first by understanding it. To do this teachers need to listen carefully to what pupils have to say about teaching, learning and schooling. The perspective also resonate with Schön's (1983) vision of the reflective practitioner. Rudduck and Flutter $(2004,145)$ emphasise the idea of teacher as researcher. 'Consulting pupils', they say, 'restores to centre stage the key professional relationship of pupils, teachers and learning It's a crucial point also for Noddings in her understanding of how moral education plays out, particularly in school. 'Dialogue', she contends, is one of 'the essential components of moral education' (2005, 22). Taking a Frierean interpretation of 'dialogue' in an educational context, she says:

Dialogue is open-ended; that is, in a genuine dialogue, neither party knows at the outset what the outcome or decision will be. As teachers and parents, we cannot enter into dialogue with children when we know that our decision is already made... dialogue is a common search for understanding, empathy, or appreciation. It can be playful or serious, logical or imaginative, goal or process oriented, but it is always a genuine quest for something undetermined at the beginning.' (Noddings, 2005, 23)

The evidence points to TY as enabling young people to find their voices; participating in such genuine dialogue with some of their teachers suggests that TY's potential in this regard is powerful. 


\section{Conclusion}

TY represents an attempt to introduce a radical change in the value-focus and curriculum practice in Irish second-level schools. In particular, it seeks to highlight a holistic, student-centred, active learning view of schooling. It challenges more traditional, authoritarian practices that reward passive engagement, rote-learning and performance in terminal written examinations (Gleeson, 2010, 157).

The evidence suggests that the project so far has being partially successful - being embraced and resisted simultaneously. There appears to be widespread consensus among students, teachers, parents and policy makers that TY contributes to increased maturity, greater confidence and more social competence and social awareness. Improved relationships among TY students themselves and between students and teachers reverberate throughout the school and impact positively on the school climate. Learning experiences beyond the classroom play a significant role in forging these improvements. In some cases, there is a perception that TY classes are more participative and democratic than the other five years of post-primary schooling.

At the same time, the evidence also points to schools domesticating TY, that is picking and choosing aspects of the programme in ways that have a diluting effect on its overall ambitions. The powerful influence of established programmes, especially the LC, generates a situation where TY is in continual danger of being colonized by values and practices associated with the status quo.

With only half the relevant cohort taking part in TY programmes, issues of systemic injustice also arise as an unintended consequence of the innovation. This is a serious policy issue within a system where inequality is widespread (Lynch, 1989; Baker et al, 2004). Despite such disparities, notable exceptions to dominant trends suggest that choices made by individual schools can be significant.

The experience of the programme's implementation points to the value of relatively small financial incentives to schools combined with focused peer support for teachers, 
especially programme co-ordinators. The evidence also highlights a curious mis-match in perceptions regarding parents’ knowledge about the initiative: parents generally indicated a serious information deficit about TY while a majority of teachers expressed the view that parents were well informed about it.

Perhaps one of the most important contributions that TY is making to the Irish education system is that it is sustaining a debate about the purpose and structure of schooling at the start of the $21^{\text {st }}$ century. As organisations, schools need to be seen as 'different) (Sarason, 1996, 318, Sergiovanni, 1996, xii), not least because they are 'transitional places for children'. Schools perform important rites of passage functions through childhood, adolescence and into wider society (Hannan, 1989, 19). The focus on 'transition' seems to be especially relevant at the present time.

Debates emanating from the TY experience tend to confirm that view that schools are ‘complex, contradictory, sometimes incoherent organisations' (Ball, 1997, 317). TY also encourages policy-makers and practitioners to mine the complex strata of beliefs and ideologies about the nature of education that pervade school contexts. In the Irish situation this exercise can unearth valuable insights into assumptions that inform day-today practice in Irish schools. Origins are important. In Ireland, as Akenson (1969), Coolahan (1981), Hannan (1987) and Inglis (1998) and others have shown, schools have been crucial sites for the strengthening of religious and social identities.

In addition to taking a socio-historical perspective on the roles schools play in society, TY prompts reflection on the Irish experience of curriculum development. It is worth recalling that an OECD review of Irish Education in 1991 remarked:

In secondary schools, the curriculum problem emerges in its most acute form. The weight of the classical humanist tradition is enormous, not least because of its underpinning of high-status occupations and a way of life which is widely admired even though unattainable by the majority. This dominance is likely to prevail unless the authorities are able to develop either a much more powerful parallel system of technical/vocational schools or a restructured general secondary education curriculum. (OECD 1991, 69) 
The increased uptake of TY since the mid-1990s can be seen as one direct response to that problem. The experience with the programme confirms how curriculum is contested, 'reflecting the cultural selection, values and aspirations of powerful social groups' (Gleeson, 2004, Callan, 2006)) rather than the interests of less powerful ones. Given its underlying thrust of challenging dominant beliefs, established practices, and existing power relations, resistance to TY is hardly surprising.

\section{Bibliography}

Akenson, D.H. (1975) A Mirror to Kathleen's Face, Education in Independent Ireland 1922-1960, Montreal and London: McGill-Queens University Press.

Arensberg, C.M. and Kimball, S.T. (1948) Family and Community in Ireland, Cambridge, Mass.: Harvard University Press.

Ball, S.J. (1997) 'Good School/Bad School: paradox and fabrication’, in British Journal of Sociology of Education, 18, pp.317-336.

Baker, J., Lynch, K., Cantillon, S. and Walsh, J. (2004) Equality, From Theory to Action, Hampshire: Palgrave Macmillan.

Browne, N. (1986) Against the Tide, Dublin: Gill and Macmillan.

Burke, R. (1974) Address to The Regional Meeting of the Dublin Education Council for Secondary Schools, at Synge Street CBS, 2 December 1974.

Callan, J. (2006) Developing Schools Enriching Learning, The SCD Experience, Maynooth: NUI Maynooth Education Department.

Commission to Inquire into Child Abuse (2003) Third Interim Report Dublin: Stationery Office.

Commission to Inquire into Child Abuse (2009) Final Report Dublin: Stationery Office (Five volumes)

Coolahan, J. (1981) Irish Education: History and Structure, Dublin: Institute of Public Administration.

Coolahan, J. (editor), (1994) Report of the National Education Convention, Dublin: Stationery Office.

Cuban, L. (1998) 'How Schools Change Reforms: Redefining reform success or failure’, Teachers’ College Record, 99(3) pp.153-177. 
Curriculum and Examinations Board (CEB) (1986a) Transition Year Option, Guidelines for Schools, Dublin: CEB.

Darling-Hammond, L. (1997) The Right to Learn, A Blueprint for Creating Schools that Work, San Francisco: Jossey-Bass.

Datnow, A. (2002) 'Can we Transplant Educational Reform, and Does it Last?' in Journal pf Educational Change, 3, 215-239

Day, C., Stobart, G., Sammons, P., Kington, A. and Qing, G. (2007) Teachers MatterConnecting Lives, Work and Effectiveness, Buckingham: Open University Press.

Deane, S. (1996) Reading in the Dark, London: Jonathon Cape.

Devlin, M. (2006) Inequality and the Stereotyping of Young People, Dublin: Equality Authority.

Doyle, E (1990) 'The Transition Year' in Aspiration and Achievement: Curricular Initiatives in Irish Post-Primary Schools in the 1980s edited by G.McNamara, K.Williams and D. Herron. Drumcondra: Teachers' Centre.

Egan, O. and O’Reilly, J. (1979) 'The Transition Year Project', in Oideas 20, Spring.

Eisner, E.W. (1992) 'Educational Reform and the Ecology of Schooling' in Teachers College Record, 93(4), pp. 610-627

Friere, P. (1970) Pedagogy of the Oppressed, New York: Herder and Herder.

Fullan, M. (2001) The New Meaning of Educational Change, $3^{\text {rd }}$ edition, London: RoutledgeFalmer.

Gardner, H. (1984) Frames of Mind: the Theory of Multiple Intelligences, New York: Basic Books.

Gardner, H. (1993) Multiple Intelligences, The Theory in Practice, New York: Basic Books.

Gardner, H. (1999) Intelligence Reframed. Multiple Intelligences for the 21st Century, New York: Basic Books.

Gladwell, M (2008) Outliers, The Story of Success, London: Allan Lane

Gleeson, J. (2004) 'Cultural and Political Contexts of Irish Post-Primary Curriculum: Influences, Interests and Issues' in Sugrue, C., ed. Curriculum and Ideology: Irish Experiences, International Perspectives, Dublin: Liffey Press.

Gleeson, J. (2010) Curriculum in Context Partnership, Power and Praxis in Ireland, Oxford: Peter Lang.

Government of Ireland (1995) Charting Our Education Future, White Paper, Dublin: Stationery Office. 
Government of Ireland (2000) The National Children's Strategy, Our Children - Their Lives, Dublin: Stationery Office.

Government of Ireland (2005) The Ferns Report, Dublin: Stationery Office.

Hannan, D.F. and Boyle, M. (1987) Schooling Decisions: The Origin and Consequences of Selection and Streaming in Irish Post-Primary Schools, Dublin: ESRI.

Hannan, D. (1989) ‘ Schools as Organisations’ in Compass 18 (1) pp. 17-30.

House, E. (1974) The Politics of Educational Innovation, Berkely, California: McCutchan Publishing.

Hyland, M.J. (2006) Carry Me Down, London: Canongate.

Ireland, Department of Education (1976) Rules and Programmes for Secondary Schools, Dublin: Department of Education.

Ireland, Department of Education (1993) The Transition Year Programme, Guidelines for Schools, Dublin: Department of Education.

Ireland, Department of Education (1996), Transition Year Programme 1994-95 An Evaluation by the Inspectorate of the Department of Education, Dublin: Department of Education.

Ireland, Department of Education and Science (2001) Strategic Plan, Dublin: Department of Education and Science.

Ireland, Department of Education and Science (2005a), The Chief Inspector's Report, 2001-2004, Dublin: Department of Education and Science

Ireland, Department of Education and Science (2005b), DEIS, Delivering Equality of Opportunity in Schools, Dublin: Department of Education and Science

Inglis, T. (1998) Moral Monopoly, The Rise and Fall of the Catholic Church in Modern Ireland, Dublin: University College Dublin Press.

Jeffers, G (2002) 'Transition Year Programme and Educational Disadvantage’, in Irish Educational Studies, Vol. 21, No. 2.

Jeffers, G. (2007) Attitudes to Transition Year, A Report to the Department of Education and Science, Maynooth: Education Department, NUI Maynooth.

Jeffers, G (2008) Innovation and Resistance in Irish Schooling: The Case of Transition Year, $\mathrm{PhD}$ dissertation, unpublished, University of Limerick.

Kerrigan, G. (1998) Another Country - Growing Up in '50s Ireland Dublin: Gill and Macmillan.

Looney, A (2001) Curriculum as Policy: Some implications of contemporary policy studies for the analysis of curriculum policy, with particular reference to postprimary curriculum in the Republic of Ireland' in The Curriculum Journal 12 (2), pp 149-62 
Lynch, K. (1989) The Hidden Curriculum, London: The Falmer Press.

Lynch, K. (1999) Equality in Education, Dublin: Gill and Macmillan.

McCabe, P. (1995) The Dead School, London: Picador.

McCulloch, G (2005) 'Curriculum Reform, Educational Change and School Improvement' in The Practice and Theory of School Improvement, International Handbook of Educational Change, edited by David Hopkins, Dordrecht: Springer. pp $169-181$

McGahern, J. (2005) Memoir, London: Faber and Faber.

McGrath, P. with Hogan, V. (2007) Back from the Brink, London: Arrow Books.

McLaughlin, M. (2006) ‘Beyond 'misery research' - new opportunities for implementation research, policy and practice', Paper presented at 'Figuring and Reconfiguring Research Policy and Practice for the Knowledge Society': New Directions for Educational Change. St. Patrick's College, Drumcondra, Dublin, July 2006.

Millar, D. and Kelly, D. (1999) From Junior to Leaving Certificate, A Longitudinal Study of 1994 Junior Certificate Candidates who took the Leaving Certificate Examination in 1997, Final Report, Dublin: ERC/NCCA.

Mulcahy, D.G. (1981) Curriculum and Policy in Irish Post-Primary Education, Dublin: Institute of Public Administration.

Murphy, I. (1999) 'Evaluation of Transition Year in 18 Second-level Schools' in Nuachlitir do Chigirí agus Síceolaithe na Roinne, 5.

National Council for Curriculum and Assessment (NCCA) (2002) Developing Senior Cycle Education, Consultative Paper on Issues and Options, Dublin: National Council for Curriculum and Assessment.

National Council for Curriculum and Assessment (NCCA) (2003a) Developing Senior Cycle Education: Report on the Consultative Process - Consultative Meetings, Seminars and Submissions Dublin: National Council for Curriculum and Assessment.

National Council for Curriculum and Assessment (NCCA) (2003b) Developing Senior Cycle Education, Directions for Development, Dublin: National Council for Curriculum and Assessment.

National Council for Curriculum and Assessment (NCCA) (2004) Proposals for the Future of Senior Cycle Education in Ireland: Overview. Dublin: National Council for Curriculum and Assessment.

National Council for Curriculum and Assessment (NCCA) (2005) Proposals for the Future Development of Senior Cycle Education in Ireland. Dublin: National Council for Curriculum and Assessment. 
Noddings, N. (2005) The Challenge to Care in Schools, An Alternative Approach to Education, New York: Teachers College Press.

O’Brien, E. (1962) The Country Girls, London: Weidenfeld and Nicolson.

O’Brien, G. (1986) The Village of Longing Dublin: Lilliput Press.

OECD (1991) Review of National Policies for Education: IRELAND, Paris: Organisation for Economic Co-Operation and Development.

O'Faolain, N (1996) Are You Somebody? The Life and Times of Nuala O'Faolain, Dublin: New Island Books.

Rudduck, J. and Flutter, J. (2004) How to Improve your School, London: Continuum.

Sarason, S. B. (1990) The predictable failure of educational reform : can we change course before it's too late? San Francisco: Jossey Bass.

Sarason, S. B. (1996) Revisiting 'The Culture of the School and the Problem of Change', New York: Teachers College Press.

Schön D.A (1983) The Reflective Practitioner, How Professionals Think in Action, London: Ashgate

Sergiovanni, T.J. (1996) Leadership for the Schoolhouse, San Francisco: Jossey-Bass.

Smyth, E. Byrne, D. and Hannan, C. (2004) The Transition Year Programme: An Assessment, Dublin: Economic and Social Research Institute and Liffey Press.

Stake, R.E. (1995) The Art of Case Study Research: Thousand Oaks: Sage.

Stenhouse, L. (1975) An Introduction to Curriculum Research and Development, London: Heinemann.

Sugrue, C (editor) (2008) The Future of Educational Change, International Perspectives, London: Routledge.

Tyack and Cuban, L (1995) Tinkering Towards Utopia, A Century of Public School Reform Canbridge MA, Harvard University Press.

TYCSS (Transition Year Curriculum Support Service) (1999a) Writing the Transition Year Programme, Blackrock Education Centre, Dún Laoghaire, Co. Dublin: TYCSS.

United Nations (1989) Convention on the Rights of the Child, New York: United Nations

Yin, R.K. (2004) 'Case study methods' in Complementary Methods for Research in Education, Washington: American Educational Research Association. 
